\title{
THE ACTUALITY OF DEISM. AN ANALYSIS FROM THE PERSPECTIVE OF ORTHODOX ESCHATOLOGICAL THEOLOGY
}

\author{
Assist. Ph.D. Mădălin-Ștefan PETRE, \\ Faculty of Orthodox Theology, University of Craiova, \\ ROMANIA, \\ Email: petrestefan50@yahoo.com
}

\begin{abstract}
The problem we intend to tackle in our study, claims its importance precisely in the thematic antinomy of this approach, conffered by the paradox of analyzing the present through the future. However, we consider that it is much more truthful to carry out an investigation of the present state of humanity from the perspective of its ultimate, meta-historical purpose. The premises from which we start in our research are constituted by certain obvious signals coming from the present state of humanity and which indicate three aspects: 1) reversing the hierarchy of values or the high degree of relativization and contestation of the vertical axis of the apodictic sense and rationality of the world; 2) the predilection of the contemporary man for the immanent and the acute weakening of the taste for the transcendent; 3) the crisis of identity of the person on vertically and on horizontally lines. This project aims to achieve major objectives. One of these is to investigate the extent to which the contemporary world still retains the principle of sense in its evolution, and what is its optics on sense. The conclusion of our research indicates the active manifestation of deist optics on all levels of human life.
\end{abstract}

Keywords: Postmodernity; Orthodox Eschatology; Church; Science; Deism; History; Pseudo-apocaliptic;

\section{INTRODUCTION}

One can recognize certain difficulties with this approach, arising from our inherent and natural limitations. When talking about aspects of created and uncreated existence, that is about God's interactions with the man and about the future heavenly kingdom being already present in our present Church, it is necessary to resort to both the faith in God and the teaching revealed by God. Not only the Church sacraments evade common scientific introspection, but also do aspects of our created existence.

Thus, for example, the substance of some historical events or stages can be revealed in its full meaning and value only in the eschaton ${ }^{1}$. The true balance of the history of mankind will be done by God, as its Creator, Savior and Judge. Although the knowledge of future events does not belong to man, but to God, still, Jesus Christ has previously revealed us what man and all God's creation must become in order to be fulfilled.

A drawback of this study is the panoramic presentation style. On one hand, this style allowed us o put a frame around a holistic, unfragmented image of human reality, but on the other hand, our conclusions feel the lack of a more complex argumentation, which should be

\footnotetext{
${ }^{1}$ Paul Evdokimov, Femeia și mântuirea lumii [Woman and the Salvation of the World], traducere de Gabriela Moldoveanu, Editura Christiana, București, 1995, p. 12
} 
more „down to earth”, more close to our human life experience and bring a deepening of the theories presented. We tried to guide ourselves, however, using the Latin concept of Brevis Sallustiana.

We also consider a definition of the terms as being necessary in order to avoid certain equivocations regarding our approach. We therefore must define the background of the terms Orthodox Church and Orthodox eschatology.

If we will consider Church as it is commonly considered, as an autonomous institution, restricted by its own dogmas and canons, often identified with the Patriarchate, with the Patriarch or clergy, we will ab initio engage on a false track that leads us to a false conclusion. But if we instead try adhere to the complete image of the Church, we'll soon reach the conclusion that it overflows these barriers that often surround it. Here is how the Church is described in Teologia dogmatică ortodoxă: "The Church is the union of everything there is, or it is supposed to encompass everything: God and creation. It's the fulfillment of God's eternal plan: all-unity. It holds the eternal and the temporal, the last - destined to be overwhelmed by eternity; the uncreated and the created, the last - destined to be overwhelmed by the the uncreated, to become godliness; the spiritual of all categories and the matter, the last - destined to be spiritualized; the sky and the earth penetrated by the sky; the non-spatial and the spatial; me and you, me and us, us and you all, united in divine „You”, or in a direct dialogical relationship with Him. The Church is a human self, in communion with Christ as You, butin the same it is Christ. The Church is the self of the prayer of every conscious being: people, angels, saints, the prayer having a great unifying role" ${ }^{2}$.

Therefore, the Church is more an organism and less an institution, being defined as "Christ's mystical body", in which He is the Head, and His believers are His limbs. Thus, the Church is a theandric organism, that is, godly and human in the same time. According to this dichotomous nature, the Church simultaneously belongs to history and is above history ${ }^{3}$. It acts during history, adapting to it within the limits of fidelity to its Head, Jesus Christ, but it offers the world, through multiple means, the ability to overcome the finite immanence of history and turn it into a true meaning ${ }^{4}$. In this way the presence of the Church in the social reality is justified in all its aspects, including in that of a nation's education.

The essence of Orthodox eschatology is included with the things above said about the Church. This theological space does not refer exclusively to the last period of creation and, implicitly, of history, as the etymology of the term indicates ${ }^{5}$, but to the reality of the future world being already present in this world, with the help of the Church. So, the eschaton is both a present and an expected reality ${ }^{6}$.

\footnotetext{
${ }^{2}$ Pr. Prof. Dumitru Stăniloae, Teologia dogmatică ortodoxă [Orthodox Dogmatic Theology], vol. II, Editura Institului Biblic și de Misiune al Bisericii Ortodoxe Române, București, 2003, p. 214

${ }^{3}$ Pr. dr. Petre Mădălin Ștefan, Eshatologia ortodoxă. Raportul dintre eshatologia inaugurată la Cincizecime, eshatologia incoativă și eshatologia finală sau realizată a Cetății ce va să fie [Orthodox eschatology. The relationship between the eschatology inaugurated at Pentecost, the inchoate eschatology and the final or accomplished eschatology of the City that will be], Editura Mitropolia Olteniei, Craiova, 2019, pp. 130-131

${ }^{4}$ Arhiepiscop Vasile Krivoșein, Biserica sobornicească, traducere de Nicolae Crețu, Editura Sofia, București, 2012, p. 1. See also: Nikolai N. Afanasiev, Canoane și conștiință canonică [Canons and canonical consciousnes], traducere de Constantin Făgețean, Editura Egumenița, Galați, 2005, p. 39; Pr. dr. Petre Mădălin Ştefan, Eshatologia Ortodoxă, pp. 138-140

${ }^{5}$ Henry George Little, Robert Scott, A Greek-English Lexikon, Clarendon Press, Oxford, 1996, p. 699

${ }^{6}$ According to the paradox of liturgical expression: "You have given us the Kingdom that will be" ("Already but not yet"), in Alexandre Schmemann, Euharistia-Taina Impărăției[Eucharist-Sacrament of the Kingdom], traducere de Pr. Boris Răduleanu, Editura Anastasia, București, 1993, pp. 40-41
} 


\section{BACKROUND}

The background of our research has roots in certain obvious signals coming from the present state of humanity and that indicate three essential aspects: 1) the hierarchy of values is reversed, 2) the high degree of relativization and contestation of the vertical axis of apodictic sense and rationality of the world; 3) the predilection of the contemporary man for the immanent and the acute weakening of the "taste" for the transcendent; 4) the crisis of the vertical and horizontal identity of the person.

These signals can be perceived more intensely and in their whole complex meaning if we analyze them in the light of the eschatological teaching of the Church. Eschatology means finality, meaning, but also a dynamic teleological relationship between the beginning and the end of creation?

1) The hierarchy of values is reversed. American professor Read Schuchardt from Wheaton College, Illinois, in a lecture held at the Faculty of Orthodox Theology in Bucharest, spoke about this hierarchy admired once. În medieval times, he said, "the world was seen by Christians as a hierarchy having God on top of it, then the angels and heavenly creatures, then the man, followed by creation (fish, birds, animals), and having the mineral world at the bottom, the earth, and below, the hell with demons"8. For postmodernity, this hierarchy is reversed, so that, according to Professor Schuchardt, "in the new hierarchy produced by the advertising industry, the first level is occupied by money (gold - the mineral world), which dictates corporate policies. Then we have the plant world, illustrated by the ecological concern of man for a clean environment. In this new hierarchy even the animals are placed above man, again easy to comprehend if we observe the animal protection policies"9. Indeed, we live in a society in which the economy has become an idol and a destiny, and the relations between states and people are built on this ideology. ${ }^{10}$ Man is transformed into an individual (Individuum in Latin), that is, into an atomized, lonely something (not someone), undermining his true person quality (prosopon in Greek $=$ facing someone), that is, being open to communication with someone else, not turned onto himself. The Megapolis of today includes a person among objects ${ }^{11}$.

2) The high degree of relativization and contestation of the vertical axis of the apodictic sense and rationality of the worldis visible in man's dismissal of a reference value. The current views put an equal sign between the different systems: cultural, spiritual, artistic etc. The positive aspect of this is the cultivation of tolerance, dialogue and good cohabitation. However, for the love of Truth, a clear delimitation of things is necessary, because our world,

\footnotetext{
${ }^{7}$ Orthodox eschatology cannot be confined to an annexed part of Dogmatics dealing with the "last events", because it represents a "theological space" in which all the other articles on our doctrine of faith intersect. It is therefore necessary to admit the validity of the concept of inchoative eschatology, that is about to be realised, because it fully indicates the reality occurring in the Church and in the world, by linking the three events of human history, Creation, Incarnation and Parousia, in the Same Christ. Reconfiguring the pathway of creation to the Kingdom through His entire economy, Christ, even ascended to Heaven, is still the man's fellow-traveler to the Jerusalem Above. The concept of inchoative eschatology belongs to H. I. Marrou (Henri-Irenéé Marrou, Theologie de l'histoire, Cerf, Paris, 2006, pp. 81-83). But philosophy also needs a foundation on the principles of eschatology, as it argues Nikolai Berdiaev (Nikolai Berdiaev, Essai de métaphysique eschatologique, Aubier, Paris, 1946, p. 61).

${ }^{8}$ Marius Nedelcu, "Conferință despre simbolistica modernă", in Ziarul Lumina, 16 iunie 2016, p. 2

${ }^{9}$ Ibidem, p. 2

${ }^{10}$ Michel Schooyans, La dérive totalitaire du libéralisme, ed. II, Mame, Paris, 1995, p. 149

${ }^{11}$ Ioan I. Ică jr., "Globalizarea - mutații și provocări", in Ioan I. Ică jr., Germano Marani, Gândirea socială a Bisericii, Editura Deisis, Sibiu, 2002, pp. 481-493
} 
and existence in general, are built on rationality, order and harmony, which are easy to notice if we seek them sincerely, and this rationality, harmony and beauty have their foundation in personal Reason, which is the Divine Logos, that is, Christ ${ }^{12}$. Based on this rationality and order we cannot say, for example, that a song that is beautifully sung can be just as good and pleasant with the same song sang in a dissonant manner. It is our hearing, that is our God created nature, which indicates this to us. It is true that, in order to see the reality as it is, we need to have a clean inner eye, not covered or hurt by "dust". Also, a feature of contemporaneity is also the trivialization or even reversal of the axiological values of our life. To this extent, virtue is classified as weakness, and sin as virtue. In addition, because of the position of supremacy that social networks and media have taken in our lives, the clear distinction between a truth and a lie has faded, the latter being equally considered ${ }^{13}$.

Today, true culture is considered precisely that which is striking, shocking by the extravagance of novelty, defiance and challenge of the consecrated cultural values, acting under the excuse of total freedom. "Beeing postmodern, Patapievici explains, means to let suspicion fall upon meaning up to unreasonable levels"14. In today's culture the same infidelity is manifested towards apodictic truths as well as towards the moral life. Therefore, in our opinion, the word that defines the man's attitude in postmodern culture is that of ("matrimonial") infidelity, a cultural infidelity, named as such for at least three reasons: firstly, because in the contemporary culture people have abandoned the fidelity of faith in the natural beauty of the personal Divine Truth, but also in the truths founded on Him, and preferred different intellectual idols, considered in their own right (the erudition itself is considered as our supreme value); secondly, this culture has an increasing emphasis on the carnal nature, both by lowering the spiritual-intellectual level of the creative vision and by adapting it to the profile of today's man; thirdly, in postmodern culture this infidelity manifests itself as the non-recognition of any "brake" weather axiological, aesthetic, intellectual, civic etc. In other words, man's creative freedom is considered an inalienable right that allows him to manifest culturally on an infinite terrain that has no guide posts. But in this way one reaches the "lecherous superficiality of postmodern relativism" ${ }^{15}$ and penetrates into the space of the infinite evil, of which Berdiaev also speaks ${ }^{16}$.

3) Thirdly, today we find a great predilection of the contemporary man for the immanent and an acute weakening of the "taste" for heavenly life. Nowadays, almost any transcendental fragment is almost completely excluded from the horizon of human ideal and interest, and the palpable immediacy that produces diverse but superficial body satisfactions is sought with feverishness. In this sense, the truths of faith are adjusted to a lower level, corresponding to the vision of the so-called liberal human ${ }^{17}$. Professor Andrei Pleșu, seeking

\footnotetext{
${ }^{12}$ Sfântul Maxim Mărturisitorul, Ambigua, 7e, traducere de pr. prof. Dumitru Stăniloae, Editura Institutului Biblic și de Misiune al Bisericii Ortodoxe Române, București, 2006

${ }^{13}$ If we just have to refer to the "Arab Spring" or the ongoing conflicts in Ukraine, we understand the serious effects that a lie spread on Facebook had in those areas. There is no need to refer to how many families and friends break apart due to the different interpretations that are given to the messages via Facebook, although it is stated up and down that people "connect" and "socialize" using these channels.

${ }^{14}$ H.-R. Patapievici, Omul recent [Recent Man], Editura Humanitas, București, 2011, p. 243

${ }^{15}$ Ibidem, p. 243

${ }^{16}$ For more details: Cristinel Ioja, "Sensul istoric-eshatologic al culturii și contrafacerile acestuia în cadrul culturii secularizate [The Historical-Eschatological Meaning of Culture and its Counterfeits in the Framework of the Secularized Culture]", in Studia Universitatis Babes-Bolyai. Theologia Orthodoxa, vol. 57, 2 (2012)

${ }^{17}$ Sf. Iustin Popovici, Abisurile gândirii și simțirii umane, traducere de pr. Dr. Gabriel Mândrilă și Laura Mândrilă, Editura Sofia, București, 2013,p. 57
} 
a specific hermeneutic of the liturgical words Our hearts should be up there, proposes the symbolic image of the eagle: "You can never understand things if you place yourself at grass root level (...) you must, on the contrary, see things from above, see the whole field, have the integrative view of the flight" ${ }^{\prime 1}$. Obviously, the professor does not recommend adopting an obsessive attitude of superlative here, and so considering yourself intangible or looking down on the others, but taking a little height in order not to resemble the rooster trapped in the small horizon of his backyard ${ }^{19}$.

4) Another finding related to the recent man is given by the identity crisis found both vertically and horizontally in a person. According to H.R. Patapievici, the postmodern man is radically different from his traditional counterpart, who "defined himself upwards by fidelity and faith, and downwards by ancestors and tradition" ${ }^{20}$, and so had a clear identity. The man of the today is suspended in a vacuum, because, "upwards, the recent man has ceased to have metaphysical problems - because, actually, he doesn't have a Heaven anymore. Nor downwards, toward his roots, he doesn't seem to have any more problems (...) But for the common perception, the recent man is the most „liberated”, the most available, the most volatile of all human types that have functioned in a man's world up to this day "21. $\mathrm{He}$ doesn't admit a „home” for himself, because he feels good without the so-called „censorship” of the „Parental index finger”. H. R. Patapievici describes this reality of our world, in his unique way: "In the eyes of recent men, the big crime is to admit there is something out there, rather than nothingness (...) The big crime, in the eyes of recent men, is to reaffirm the very simple truth of God's existence and that without Him our world is a crazy one. The big crime, in today's fashion, is to still be a Christian"22. Being a Christian means having your own pinpointed place in the world, being connected to your own kind, to Christ and the other inhabitants of Heaven.

\section{OBJECTIVES AND ANALYSIS OF THEM}

With this background for a start, we set out certain objectives to be further explained. 1. To what extent does the contemporary world still keep in its development the principle of whole meaning of existence and how does it see the concept of whole meaning ${ }^{23}$ ? Also, to what extent can the whole meaning of today's man, as he understands it,

\footnotetext{
${ }^{18}$ Andrei Pleșu, Despre frumusețea uitată a lumii, Editura Humanitas, București, 2011, p. 17

19 Sf. Siluan Athonitul, Intre iadul deznădejdii și iadul smereniei, traducere de diac. Ioan I. Ică jr, Editura Deisis, Sibiu, 2001, p. 143

${ }^{20}$ H.-R Patapievici, Omul recent, p. 301

${ }^{21}$ Ibidem, p. 304

${ }^{22}$ Ibidem, pp. 300-301

${ }^{23}$ Man and mankind, in general, are thirsty for a meaning or knowledge that could reveal a target and lead them to a certain ideal. The first man was not created and allowed by God to spend in Heaven without a particular purpose, but his existence was meant for reaching new horizons. As we have pointed out above, eschatology is closely linked to cosmology, because God wanted, through creation, to instill into His beings a motion towards a certain purpose. He wanted the created nature to become a deified nature, but only through free participation, and that is why He gave man the opportunity to move alone towards that goal. Therefore, man, who had to gather in himself the whole visible creation, could only achieve perfection by moving towards a Target which is none other than the Reason of his existence. This is asserted by Saint Maximus: "Everything that moves, it moves, of course, for a reason. And everything that moves for a reason, it exists for a reason. And everything that exists and moves for a reason has, of course, originated from the reason of which it exists and for which it was brought into existence, and as target (telos) of the motion, the same reason for which it moves and towards which it rushes" (Sfântul Maxim Mărturisitorul, Ambigua, pp. 340-341). Also, the divine image of man indicates not only what man is, but especially what he must become and, through him, the cosmos around him.
} 
be interpreted as one that fulfills him as a created creature? In this investigation of ours we will have The Incarnation of the Son of God and the foundation of the Church as an absolute reference, because these are godly and human acts intended to reconfigure the path of creation towards its final target and to rediscover the meaning lost by the sin of Adam. Therefore, according to the Holy Fathers, the founding of the Church coincides with the inauguration of eschatology, that is, with the re-opening of the Kingdom of God for men ${ }^{24}$. This is also the role of the Church entrusted by Christ, to maintain the orientation of humanity inside its ontological sense, even if apparently the Church has no obvious, visible power. It represents that little dough that ferments and grows the whole kneaded dough or that tiny mustard seed from which a large tree sprouts, and the fruits of this tree, the saints and the righteous, will be seen ripe only at the end of history ${ }^{25}$.

We must also differentiate the personal meaning of existence of today's man and the general meaning adopted by mankind. These two views intersect, and normally, the first should influence the second, because the person should influence the social, and not the other way round. It seems that collectivist theories have the maximum applicability today, and it is unfortunate, because the person is the one influenced, determined and adjusted according to the impersonal and harmful morphology of the surrounding landscape. Therefore, one can find that the meaning assumed worldwide and imprinted by corporations and other macroorganisms has the force to visibly influence the existential meaning of the man, by proposed and imposed directions that are dissonant with many aspects of man's nature and purpose, and with particularly important characteristics of the ethnic, cultural and spiritual environment ${ }^{26}$. The man is, indeed, an adaptable creature, but it is notable that this necessary adaptability must be positive and healthy. It's true that today one can hardly make the distinction between positive and negative, good and evil, truth and lies, beauty and ugliness etc. So, what is the REFERENCE on which or against which these distinctions should be made? Or where can we look to see Someone who showed the highest state of perfection in man? An examination of time and space leads us only to Christ, with whom man reached godliness, and so fulfilment. It's with Him that the man who believes and follows Him can see in advance what he himself can become ${ }^{27}$. This truth can actually be seen in a concrete form in all the saints of past and present. The beauty of Christ is reproduced in the beauty and might of the saints ${ }^{28}$. Of course, we talk about the beauty of holiness, purity and therefore, the might of the divine gift. As such, it is absolutely natural that any view on the meaning of

All the aspirations and impetuses of man for eternity, perfection, truth, so for God, are concentrated in this image. "Therefore, the postulates of the knowledge of God are in the very structure of his being", and that is why, as Evdokimov very aptly states, to know God means, more precisely, to "recognise" Him (Paul Evdokimov, Cunoașterea lui Dumnezeu în Tradiția răsăriteană [La conaissance de Dieu selon la tradition orientale], traducere de Pr. Vasile Răducă, Editura Humanitas, București, 2013, p. 38).

${ }^{24}$ Pr. dr. Petre Mădălin Ștefan, Eshatologia ortodoxă, p. 122

25 Rev. Assistant PhD Mădălin Ștefan Petre, "Un synthése de la theologie eschatologique orthodoxe", in Journal Orthodox Theology in Dialogue, No. 4 (2018), p. 41

${ }^{26}$ W. Andreff, Les multinationales globales, La Découvert, 1996, pp. 34-40

${ }^{27}$ Pr. Prof. Dumitru Stăniloae, Teologia Dogmatică Ortodoxă[Orthodox Dogmatic Theology], vol. II, pp. 119120. In the same vein, Evdokimov states : "If the Old Testament was headed towards Messiah, after the Day of Pentecost the ecclesial time changed in the direction of those parusial novissima, leading man to the perfection of the new creature - a real novelty, for God Himself becomes new Man - ecce Homo, absolute Man - being followed the whole world" (Paul Evdokimov, Iubirea nebună a lui Dumnezeu [L'amour fou de Dieu], traducere de Teodor Bakonsky, Editura Anastasia, București, 1999, p. 69)

${ }^{28}$ Pavel Florenski, The Pillar and Ground of the Truth, Oxford University Press, 2004, p. 87 
existence be judged from the perspective of this PERSON-REFERENCE, who is THE GODMAN, CHRIST.

The problem of the meaning of life of each one of us is a matter of life and death, because this is one of the main characteristics that separates man from animals. We are not talking here about the concern for our future in the world, a concern we find in animals, in their sense of preservation, but about a discovery of our true meaning in the world, a meaning which can never be restricted to one ideal or another that are trapped in this the world. To find the meaning of life means to discover the true scale of values, that is to know who you place on top of the pyramid and you climb to in order to escape the world's nothingness. By simple word, Christ inversed the pyramid, the scale of values: "For what is aman profited, if he shall gain the whole world, and lose his own soul? orwhat shall a man give in exchange for his soul?" (Mt. 16: 26). So, Christ, the Creator of both the world and soul, knows best the value of each one, and this is not difficult even for us to notice if we want to justly see reality, thinking only that at the moment of death everything evades us: power, influence, wealth, health, courage. Therefore, the meaning of our life must overcome the fleeting and fragile reality of material existence.

In our days, it seems people are less and less concerned with what represents a meaning of one's life, and this is not a positive signal, because, as professor Andrei Pleșu says, "a life during which one never asks himself about the meaning of life is a life without an autonomous meaning. Life tends to make sense as soon as you ask yourself about its meaning" ${ }^{29}$.We have to admit, that to ask ourselves seriously about the meaning of our lives, we need courage, because at that moment the whole dialectic on which our view was based is turned upside down and the process becomes awkward. Still, it is worth the effort.

From the experience of those who consciously asked themselves about the meaning of life and found answers, one can say that these answers are not what everyone else would expect. „The common mistake,” says Andrei Pleșu, "that affects the talk on the meaning of life is the mistake between ,meaning' and ,program'. The majority of people tend to believe that an honorable life program (starting a family, making a career, the duty towards the community etc.) has the necessary substance to constitute a meaning of life. Actually, we are talking about simple, reasonable „objectives”, and meeting them leaves the meaning problem unsolved, if not dramatically amplified. The question about the meaning of life pops up, in its spectral nudity, as soon as (and specifically because) one meets his/her objectives" ${ }^{30}$.It is so that, for example, in history, many people with brilliant careers as actors, teachers, dignitaries, militaries, all of the sudden, and shockingly for their contemporaries, dropped everything and started a new way of life. These people were suddenly struck by such clarity and vision, inspired by the answer to the question about the meaning of life. This answer is not revealed by the strength of argument, but by conviction of the heart, which is the only one that is able to admit its validity. The heart is the one that feels that the answer found fulfills it, pushes out any reserve or contradiction. Essentially, this answer is finding the way to achieve eternity, finding God Himself ${ }^{31}$.

As I mentioned before, the problem of the meaning of personal life intersects with the problem of the meaning of humanity as a whole, and there are not just a few people who have been concerned about the latter. Until recent, these concerns were reserved for

\footnotetext{
${ }^{29}$ Andrei Pleșu, Despre frumusețea uitată a lumii, p. 33

${ }^{30}$ Ibidem, pp. 33-34

31 Arhim. Sofronie Saharov, Cuvântări duhovnicești, traducere de Ierom. Rafail Noica, Editura Reîntregirea, Alba Iulia, 2004, p. 87
} 
philosophy and theology, but in modern and postmodern times they are thrown into the arms of science, which is considered the most capable to decide on the essential problems of humanity. The postmodern man does not have any more time nor taste for philosophy, he feels it's useless to train his mind, and worry about ideas that overburden it. Also, theology or Christian teaching does not enter its area of interest, because it speaks of intangible things that, consequently, do not exist. Finally, he vouches the claims or conclusions of the science that came by media channels, which, without being a little ruminated on, are assimilated, are chugged as such because they are "SCIENTIFIC".

So, the preoccupation over the meaning of humanity and our global existence is considered to be the field of science. Our amazement lies in the fact that, although we were taught by the revelation of Christ about the essential truths of our existence, of the whole creation, of our relationship with God and the real ways, proven by Christ Himself and by the multitude of saints, that by faith in Christ, man and creation reach their finality, however, science ignores all this revelation and always looks for ways to find out where we come from and where we are going. Starting with the modern times, science manifests an obsession to demonstrate that the Christian Revelation is not true, that God does not exist or exists in a way that science wants, that everything is not God's creation, but the result of evolution ${ }^{32}$, etc. In our time, it seems that the world has entrusted its concerns to the question of our origin and meaning to the British professor and researcher Stephen Hawking, who has wanted all his life to demonstrate precisely what for Christians is so evident and an $\mathrm{ABC}$ of our existence. These are his main challenges:

"However, if we truly discover a complete theory, it must be roughly understood, in time, by virtually anyone, not just by scientists. Then we all: philosophers, scientists and common people should be able to take part in discussing the problem: why we and the universe exist. If we find an answer to that question, it would be the final triumph of the human mind - because then we would know the thought of God"33.

"We will prevail and formulate a complete theory of the universe. In that case, we will truly be its Masters" ${ }^{34}$.

"I hope we will find a consistent model to describe everything in the universe. If we do it, it will be a triumph of the human race" ${ }^{35}$.

"The conviction that the universe is governed by an order that we can partially perceive now and that we'll be able to fully understand in a not so distant future. It may be that this hope is nothing but a delusion; it may be that there is no final theory and, even if one existed, we may never find it. But it sure is better to struggle for a complete understanding than to surrender to the despair of human spirit"

"We find ourselves in an amazing world. We wish to find a meaning for everything we see around us and we ask ourselves: What is the nature of the universe? What is our place in the universe and where did it come from? Why is it the way it is? ${ }^{137}$.

\footnotetext{
${ }^{32}$ The scientist does not invent something by himself, he does not produce new realities, but he uses the data taken from God's creation describing it, that is, what the Creator established from the beginning. Petre T,uțea rightly said that "only God is original, and Aristotle is not original, for he merely describes the work of God. But Aristotle, no doubt, is a genius, for he brilliantly describes the work of God" (322 de vorbe memorabile ale lui Petre Țutea, Editura Humanitas, București, 1997, p. 79).

${ }^{33}$ Stephen Hawking, A brief History of Tim, 1988, p. 200

${ }^{34}$ Stephen Hawking , Black Holes and Baby Universes and others essays, 1993, p. 14

${ }^{35}$ Ibidem, p. 56

${ }^{36}$ Ibidem, pp. 14-15

${ }^{37}$ Stephen Hawking, A brief History, p. 196
} 
So, St. Hawking, one of the fervent activists of science of our century, takes the burden of humanity's existential questions on his shoulders. The preoccupation for these sharp questions is nevertheless positive; it is the most prominent sign of the fact that man cannot be classified by the evolutionist ,genealogy” of Darwin and his supporters. Although St. Hawking shares belief in Darwin's theory of "natural selection", yet he is commendable because he has raised such questions in all seriousness. But his fundamental error lies in that he doesn't notice that such questions cannot be answered by any living organism in the world, with the exception of man, who by constitution, and so by special creation, one thought by Somebody, transcends the sensitive world. And what is the essence of such questions? It is turning onto one's self, questioning one's own self, talking to one's self, that is, the conscience of one's own existence. This wonder cannot be the product of any evolution of matter, organisms, no matter how prolonged it would be. It is something that transcends matter; it is a divine gift, the essence of a person, created after the face of God, in His holy trinity.

We must also admire professor Hawking because, by raising such uncomfortable questions today, he steps aside from the crowd that is content with the reductionist view of an animal existence.

When they find expressions that contain God inside Hawking's system of thinking, lots of people deceive themselves by saying the British professor is a pious scientist and he is not against religion. We must contradict this view, because with Hawking, as it is with lots of scientists and philosophers, God is not a personal religion, but just an idea, a dead investigation object, which is one and the same with atheism. René Guénon reminds us that even those truly pious scientists, in their „scientific” approach, they break with their internal convictions. This approach to things integrates with the past and present deistic, chameleon view, as stated by the French philosopher: "It is certain that this science does not make atheism or materialism a vocation, but only deliberately ignores certain things, without formally denying them, as some philosophers do: so one cannot speak, in its case, of a declared materialism, but only of what one would call a practical materialism; but the evil is perhaps even greater in this case because it is deeper and more widespread" ${ }^{38}$.

Anyway, out of many of Hawking's statements, we can understand that in his science he wants to get rid of God from the key-points of the equations of the universe: origin, functionality and its finality.

If these scientists were sincere and did not start their journey of research with the preconceived idea of fighting God and the Christian tradition, they would have countless reasons, because of the results of their observation and research, precisely to acknowledge God in the three keypoints of creation ${ }^{39}$. Both A. Einstein and St. Hawking bumped into the evidence of a rationality, of a preset order and of a harmony that only a Person could think and establish, but unfortunately, these were put on account of events or autonomous internal processes. Moreover, A. Einstein had the courage to emit that famous statement: "God does not play dice!"

So Hawking, in the above statement, considered that he could penetrate "God's thinking" and find out "why we and the universe exist", as if God created such a beautiful universe and such a wonderful creature, the man, and then He does not want to know about these, nor these about Him. For the Fathers of the Church, not knowing God means not

\footnotetext{
${ }^{38}$ René Guénon, La crise du monde moderne Les Editions Gallimard, Paris, 1946 , p. 127

${ }^{39}$ Malcom Bowden, True Science agrees with the Bible, Sovreign Publications, Bromley, 1988
} 
knowing ourselves and the rest of the universe. Man get an explanation about himself, not just by the surrounding material reality, but through God Himself. In the thoughts of Saint Athanasius the Great, for example, the man, without the knowledge of his Maker and without the connection with Him, would not differ essentially from the rest of creation: "What benefit would the created ones have if they didn't know their Maker? Or how would they be rational, not knowing the Word (Reason) of the Father, by which they were created? They would make no difference from the non-rational (non-speaking) kind, if they knew nothing more than the ones around them. And why would God have made them, if only not he had wanted that they know him?"40.

Hawking wanted to know an essential law of the universe on the basis of which to discover both the origin and the future of the universe. He is not discouraged by the idea that the beginnings of creation are the field of metaphysics and religion, but he believes "that the initial conditions of the universe are also suitable as a subject of scientific study and theory, as local physical laws are" ${ }^{41}$. Very well. No one stops him in his efforts. But also in this regard the teacher makes a fundamental mistake. He wants to know the beginnings starting from what the present indicates to him, but often stumbles in his argument. If he accepts Edwin Hubble's theory regarding the expansion of the universe and arrives, over time, to the singularity called the Big Bang, he concludes that the idea of the Big Bang theory is good for explaining a beginning, and yet he states that "science could not explain why was the universe the way it was after the big bang" ${ }^{42}$, that is, why did it develop so harmoniously and perfectly ordained? Hawking is actually sincere when he claims that he needs God to complete his scenario, but the researcher gives Him the task he wants and not the one that God wanted. We shall return to these aspects in the next chapter. Thus, Hawking makes it clear that the origin of the universe has something transcendent to it, which goes beyond the laws of science. His claim, scientifically based, is similar to Christian dogma, according to which the event of creation of the world is accepted by faith, because the Genesis is a divine act, beyond what we can rationally investigate. Therefore, to scientifically study creation the way it is at present is one thing, and to know its origin is quite another.

Statements like this: "The creation of the world - the fact is often overlooked - is not a philosophical (and scientific) truth, but an article of faith" 43 should not convey the idea of an invitation to ignorance, to "fumbling in the dark", according to Hawking's expression, but in a different way of acquiring this truth, of experiencing it or even seeing it, as scientists want to be convinced. Father John Romanides clearly states, according to the whole experiential tradition of the Church, that "the things on the creation of the world are known by someone who has come to deification, because in this state he sees the things of the Father, but also those who are from nothing" ${ }^{44}$. Therefore, knowing firstly the Father, offers full knowledge of the creation, obviously, in its essential, not scientific, truths, or, according

\footnotetext{
${ }^{40}$ Sfântul Atanasie cel Mare, "Tratat despre Întruparea Cuvântului și despre arătarea Lui în trup", III, 11, in Coll. Părinți și scriitori bisericești (PSB), vol. 15, Editura Institutului Biblic și de Misiune al Bisericii Ortodoxe Române, București, 1987

${ }^{41}$ Ibidem, p. 59.

${ }^{42}$ Ibidem, p. 94.

${ }^{43}$ Vladimir Lossky, Teologia mistică a Bisericii de Răsărit [The Mystical Theology of the Eastern Church], Editura Anastasia, București, 1995, p. 121.

${ }^{44}$ Ioannis Romanidis, Teologia patristică [Patristic Theology], traducere de pr. Dr. Gabriel Mândrilă, Editura Metafraze, București, 20011, p. 244.
} 
to Saint Maximus the Confessor, "the visible will be understood by the unvisible"45. Science does not respect the order of priority in knowledge. It wants to know the creation without the Creator, so without putting it in His light. Human reason is impatient and wants to encompass everything within its sphere of understanding. This is why, in the early Christian times, the initiation consisted in knowing God as Creator by faith, and then, gradually, by sight: "First of all, believe (author's highlight) that there is One God, the One who created and framed all things of nothing into a being, $\mathrm{He}$ comprehends all things, and only is immense, not to be comprehended by any" ${ }^{46}$.

Looking at it from another angle, we can ask: why do we think God created the world? Because the Same God has convinced us in countless other points that $\mathrm{He}$ is God and can do whatever He wants. He convinced us through facts about His personal reality and about many other things. Therefore, we believe everything He has revealed to us. In addition, this faith is supported and confirmed by millions of martyrs and saints. The martyrs of Christ have confessed that God is the Creator of the whole universe and the Saviour, showing greater confidence in the unvisible world than in the world felt through their senses, doing so with total assumption, with firm lucidity, with much love for God and people and especially without any trace of fanaticism.

2. The excessive fragmentation of today's social reality made us add the research of its subliminal causes as another objective of this project. It seems that in this situation we are talking about a much more complex reactivation of deism ${ }^{47}$. Essentially, the deism means an artificial distance between the created and the uncreated, and this vertical discontinuity produces horizontal segregation and self-destructive circularity exclusively in the immanent area. Today, deism goes beyond the religious sphere, contaminating society in all its compartments. Not disputing the existence of God, but isolating it somewhere in the sky, society gives up the main binder of its components, its segregation being inevitable. In this respect, we can speak not only of a religious deism, but also of a political one (the separation of the State and the Church), of a philosophical one (God is seen only as an idea), of a scientific one (God is no longer recognized as being actively involved in the functionality of creation) and of a sociological one (the presence of God in the daily life of man is replaced by rhetorical sequences about $\mathrm{Him})^{48}$.

Due to this active deism, religion is perceived as a feeling of dependence and not as one of independence from the contingency of the world ${ }^{49}$. However, the solution can only come from religion, in this case Christianity, which must regain its role as a unifying element of those components of social reality, because, only by making them function together, humanity is moving towards a higher ideal. Eschatology means nothing more than achieving full unity in God and the Trinity, by divine gift.

\footnotetext{
${ }^{45}$ Sfântul Maxim Mărturisitorul, Mistagogia[Mistagogy], 2, traducere de pr. Prof. Dumitru Stăniloae, Editura Institutului Biblic și de Misiune al Bisericii Ortodoxe Române, București, 2000

46 "Păstorul lui Herma", Porunca I, in Scrierile Părinților Apostolici, PSB, vol. 1, Editura Institului Biblic și de Misiune al Bisericii Ortodoxe Române, București, 1979

47 Deism, a heresy that appeared in the early Christian centuries, supports God as Creator, but not His participation in the course of creation and history. Over time, deism has taken on different forms, being quoted mainly in philosophy by refusing the revelation and attempting to explain everything without God. For more details, see A Theological Dictionary, Philadelphia, 1838.

${ }^{48}$ H.-R. Patapievici, Omul recent, p. 73

${ }^{49}$ Nikolai Berdiaev, Essai de métaphysique eschatologique, p. 257
} 
In a first phase, deism states the discontinuity between the moment of world's Creation and the intervention of God into the world and its history ${ }^{50}$. In the second phase, the new deism seeks to break humanity apart from the event of God's incarnation, as second creation or as a moment by which God reconfigures the path of creation towards its eschatological objective, so by which $\mathrm{He}$ reveals and points towards its ontological meaning $^{51}$. Deism also discourages the affirmation of the link between Creation and Incarnation: „In the beginning God created the heavens and the earth” (Gen. 1:1) and "In the beginning was the Word... The Word became flesh and made his dwelling among us" (Jhn. $1: 1$ and 1:14) are the two essential discoveries, the two landmarks of our existence ${ }^{52}$, by which we are informed that the created world can exist and function only by means of the uncreated power of his Maker who "is dwelling among us", in the Church. But even the existence of the Church is seen as disconnected from its everlasting and uncreated fountain, and assimilated with any other religious organization in history. But the Church is that in which Christ joins the two events, the world's Creation and the Incarnation, with the third, which is Parousia (Second Coming) and the discovery of the Kingdom to come. So the very existence of the Church is clear proof of a meaning, one that is beyond this world, but the world is reluctant of any meaning, all the more so of a meaning that indicates other dimensions than the immanent. The world prefers a Church that is captive in time and a submitted to history. Even if the Orthodox Church is reproached for being anachronistic, it cannot give up its Truth and views of life, because it would be consigned to the relativity of history. It doesn't want to be chameleonic. If in the present there is an infinity of religious beliefs, of socio-political views, the Church still remains faithful to the same anthropological profile, which is Christ, God - the Man, and in Him people see how they must become, starting from the time of history, and beyond it.

The current religious deism, with deep roots in the Middle Ages (the separation of the papal Church from the Eastern Church, the Reformation with all steps taken downwards from the original tradition, etc.) and in the modern era (the Enlightenment, the French Revolution), manifests itself in different aspects. There is a deism outside the Church and one within. The former does not remove faith from the equation of human existence, but sees it as a social product and, as such, its role is nothing more than social. J. H. Randall sees nothing in human life that really transcends it. Instead everything is the result of human imagination:

"All ideas and settlements are today thought of primarily as social products, functioning in social groups and arising from the necessity of achieving a certain adaptation of human nature to the environment. All areas of human interest today have been subjected to this general social and psychological tendency, with religion and theology being edifying examples in that sense. While the eighteenth century regarded religion as a set of deductive and demonstrative sentences, people today regard religion primarily as a social product, a way of life arising from the social organization of people's religious experiences, and theology as a rationalization of certain fundamental feelings and experiences of the human nature. We no longer seek to prove the existence of God, but we instead speak about "the meaning of God in the human experience"; we no longer seek to demonstrate the future life, but we investigate the effect of the faith in immortality on human behavior" ${ }^{\prime \prime 3}$.

\footnotetext{
${ }^{50}$ H.-R. Patapievici, Omul recent, p. 91

${ }^{51}$ Pr. dr. Petre Mădălin Ștefan, Eshatologia ortodoxă, p. 101

${ }^{52}$ Calist Patriarhul, "Capete despre rugăciune", in Filocalia, vol. VIII, traducere de pr. prof. dr. Dumitru Stăniloae, Editura Institului Biblic și de Misiune al Bisericii Ortodoxe Române, București, 1979, p. 354

${ }^{53}$ J. H. Randall, The Making of Modern Mind, Mufflin Company, Houghton, 1940, p. 478
} 
Randall's assertions are real, because they express the result of his research, but they are valid only on certain segments, so they cannot have general value. The data of his problem would have changed radically if he had known the life of an authentic Christian, of a man with a holy life, or even if had read about the lives of some of the saints. Nobody contradicts the social implications of faith, but it cannot be cloistered under this hat. Randall's opinion, largely shared in today's society, come from mixing all religions in the same pot. But "Christianity is not a „religion" in the sense of a distinct, well separated, compartment of the existence, it has the depth of the entire life itself, when Resurrection fills it"54.Also, "Orthodoxy is not religion. Because religion equals superstition. The religious man is a superstitious man, who has some thoughts about God and who takes refuge, superstitiously, in religion, either for help, in order to overcome the difficulties of this world, either out of fear of death, poverty or psychological insecurity"55. Marxism was based on these false premises. It considered that religion would become useless when there will be no more poor people in the world, as if religion was the monopoly of the poor. Orthodoxy is not a comforting pietist religious practice, nor a theoretical doctrinal system, but a "divine-human science" in which man is healed, that is, renewed according to the model of Christ ${ }^{56}$. Therefore, from a certain point of view, it can be seen as a positive science, in connection neither with ecstatic or meditation practices nor with epistemological theories, such as, for example, "logical positivism" ${ }^{57}$, and in this sense the saints are the argument. Therefore, the argument of Orthodoxy is rather given by argumentum ad verecundiam ${ }^{58}$ and acta non $v e r b a^{59}$, from which everything else is derived.

As we were saying, Randall's statements are inspired by a certain reality of today's Christianity, inside which we can observe that life in Christ is assumed on a superficial level. American father Seraphim Rose, who was a charismatic man especially in terms of his ability to understand and express the depths of the decaying state of the world, also notes that the existence of eternal life is not denied everywhere in a direct manner, but, nonetheless, it is neither the subject of any sincere belief. According to Father Seraphim, there are two main forms of such equivocal attitudes: one is the Liberal Protestant, also infiltrated in the Catholic and even Orthodox environments, which is displayed as a "minimal faith" in the future life seen as "a place where you receive" your well-deserved peace "after a life of hard work", but this "faith" is in reality only "an emotional projection, a consolation"; the other conception is even more blurred, being specific to humanism and expressed in various forms of culture. It uses the idea of eternity only at the level of style or rhetoric, using bombastic expressions

\footnotetext{
${ }^{54}$ Olivier Clement, Sillons de lumière, Fatest/ Cerf, Troyes, 2002, p. 28

${ }^{55}$ Ioannis Romanidis, Teologia patristică, p. 137

${ }^{56}$ Ierotheos, Mitropolitul Nafpaktosului, Dogmatica empirică după învățăturile prin viu grai ale părintelui Ioannis Romanidis[The Empirical Dogmatic after the Oral Teachings of Father Ioannis Romanides], Vol. I, traducere de Tatiana Petrache, Editura Doxologia, 2014, pp. 141-144

57 Thus, "the Orthodox theology has no connection either with cogitation, nor with any form of exaltation or meditation" (Ioannis Romanidis, Teologia patristică, p. 136), and nor with those epistemological theories or scientific concepts such as, for instance, the "logical positivism" (The Cambridge Dictionary of Philosophy, Cambridge University Press, 1999, p. 514).

${ }^{58} \mathrm{An}$ argument based on the recognition of the truth of a statement because it was made by a person posessing authority, who enjoys a reputation. With Christ, His words are identified with His person : Septimiu Chelcea, Cum să redactăm o lucrare de licență, o teză de doctorat, un articol științific în domeniul științelor socioumane, București, 2003, p. 158

59 „Implebatque actu quiquid sermone docebat” (Words written on the epitaph of St. Gregory the Great).
} 
without precise content, such as "eternal truths" or "the eternal spirit of the people"60. It's clear that the absence of faith in the existence of future life and judgment leads to an ethical relativism, because, given the reality of the homo homini lupus principle, "a higher and better moral than that of an animal can be based only on the sense of human immortality" ${ }^{\prime \prime}$.

The artificially created separation between the social reality and the religious life of a man can also be observed in the manner of building an ethical system of our existence. Therefore, out of the obvious need for an ethical code, we have reached a moral autonomy created by man and founded on the man. As such, "man is governed on earth by two morals: the moral of dogmas, which is Christian and eternal, that is, absolute, and the moral of norms, which, as a secular morality, is built on man's smallness and imperfection. Secular morality cannot be detached from absolute morality and it shows that man moves asymptotically to perfection, which he can never reach" in the plane of history, but beyond it ${ }^{62}$

The separation between the School and the Church is another example of active deism in contemporary reality, and this artificially created dichotomy, as if there was a incompatibility of principle between them, was supported by two essential measures: removing the icon from the classroom and religion class from the common core curricula.

Regarding the icon, in the VIII-th century there was a fierce struggle in the Byzantine empire to eliminate it from the public and private life of Christians (the iconoclasm) ${ }^{63}$, and fight against this "danger" is manifested to this day, being replaced by the statue in Catholicism and by nothing in Protestantism and in the other confessions. What is the reason man fought against the holy icon? The opponents' response was idolatry. This was and is, in fact, a pretext with deep traces in the conscience. Through the features of a slender, spry body, not overwhelmed by pleasure's greed, the Icon shows the holy, clean man, his victory over sin. The statue can only express the lusty, self-sufficient man, as in the case of the ancient Greek statues. As such, the man of yesterday and today, eager for a life full of pleasures does not feel comfortable around an icon, because its presence raises its consciousness, shows him how the man should be. It is all about that "refusal of the face" in modern $\operatorname{art}^{64}$ or about the hiding from transcendental eyes and their admonitory gaze upon us. That is why the presence of the icon in the school rather embarrassed the adults than the children, because the children are attracted by their own purity towards the icon. When pupils were asked the question "What do you want to be when you grow up?", one child answered: "I want to be saint."

\footnotetext{
${ }^{60}$ Eugene (Fr. Serafim) Rose, Nihilism. The Root of the Revolution of the Modern Age, Saint Herman of Alaska Brotherhood, Platina -California, 2001, pp. 38-39. Father J. Romanides also speaks of two levels of faith in man. It is necessary to overcome the first level in order not to remain only at that deistic level with tendency of social and psychological interaction, which Randall recalls: "There are two faiths in man. One is encephalic, the rational faith of acceptance. In this case man logically accepts and believes in what he accepts. But this is not the faith that corrects (heals) man [...] The other faith is the faith of the heart [...] This faith is the gift of God [...] But the inner faith comes from the experience of the Grace", so it must not be confused with emotionalism, but it is the gift of the prayer of the heart (Ioannis Romanidis, Teologia patristică, p. 83).

${ }^{61}$ Sfântul Iustin Popovici, Abisurile gândirii și simțirii umane, pp. 96-97

${ }^{62}$ Petre Țuțea, 322 de vorbe memorabile ale lui Petre Țuțea, p. 71

${ }^{63}$ L. Bréhier, La querelle des images (VIII-Ixe siècles), II éd., Paris, 1904 ; A. A. Vasiliev, Istoria imperiului bizantin, traducere de Ionuț-Alexandru Tudorie, Vasile-Adrian Carabă, Sebastian-Laurențiu Nazâru, Editura Polirom, Iași, 2010 ; A. Grabar, Iconoclasmul bizantin, Editura Meridiane, Bucuresti, 1991; Alain Besancon, The Forbidden Image: an Intellectual History of Iconoclasm, translated by Jane Marie Todd, Chicago, 2009; Nicolas Ozoline, "The Theology of The Icon”, in The Greek Orthodox Theological Review, $1 / 4$ (1993) etc.

${ }^{64}$ Olivier Clement, Sillons de lumière, p. 43
} 
The second argument was related to the religion classes, even in the traditional and mostly Christian states. The problem is very complex and there is no place here to develop it. We mention only two aspects: 1) education is incomplete if it does not involve both erudition and virtue; 2) the presence of the religion classes does not mean any damage on freedom or any hegemony of the Church. We cite here the words of Professor Andrei Pleșu as an argument: "I keep hearing that, through the religious education in the school, a ready-made 'ideology' is inoculated in the 'victims', and they were not given the chance of free choice. It's a non-sense of a pedagogical principle. If all children were invited to choose "freely" between school and play, most of them would probably choose to play. Why does no one protest because those poor students are bound by a discipline they have not chosen voluntarily? Learning the meaning of liturgy, communion, eucharist, wafer, confession, icon and so on does not necessarily lead to confessional captivity, bigotry or becoming a priest. The world is full of atheists born in pious environments. Not to say that without a religious education, you cannot even be a true atheist, you are only the captive of an irrational idiosyncrasy. Do we want freedom of choice? Then let us proclaim any form of education as optional. Nobody asked me if I wanted to study organic chemistry in high school. Why would they ask me if I want to study religion? There is but one answer to this question: unlike organic chemistry, religion is an "opium" ... We shall then move it, by Marx's example, to the study of opioids. At the moment, it is not clear to me why the study of religions is an insidious "intoxication", and anti-religious propaganda is not. Why would children be denied the right to a complete education, the right to be knowingly free and, above all, the right to receive a strong education, not by the measure of a social decree, or of the conventional etiquette, but by participation in the more subtle order of the world, which secularization puts, with arrogance and ignorance, in brackets?" ${ }^{65}$.

Also, the linking of the Christian religion with the class hours has the role of giving students a reference both horizontally and vertically, as Olivier Clement argues: "In a truly pluralistic society, one would hear about the Bible in school - otherwise the young people would not have access to their cultural heritage - one will hear about the Fathers of the Church in the study of thought, the children will be familiar with a spiritual anthropology with the universe of signs and symbols"66. What O. Clement admitted, we can confirm from our experience. I remember that in my school years the history teacher presented us with the origin of man according to the theory of evolution, supporting his argument with those images of human evolution up to homo sapiens sapiens. For me it was a disappointment, as it is with any child when he learns that Santa Claus doesn't exist. However, I was still going to church on Sunday and, in conversation with Christ and the Mother of the Lord, I intuitively understood that man is related more to those heavenly Persons than to the monkey. This saved me, I now understand that in the church you can grasp man's definition. "You are compared to God, there, because you express His face and likeness" ${ }^{167}$,that is, you are a person. The person represents the "irreducibility of man to nature"68.

As we now come to the talk about the theory of evolution, we must point out that this is perhaps the most obvious deist innovation of modern man, with powerful effects over the present. Fighting this theory is not the subject of the present study. We are only indebted

\footnotetext{
${ }^{65}$ Andrei Pleșu, Despre frumusețea uitată a lumii, pp. 144-145

${ }^{66}$ Olivier Clement, Sillons de lumière, p. 30

${ }^{67}$ Petre Țuțea, 322 de vorbe memorabile ale lui Petre Țuțea, p. 23

${ }^{68}$ Vladimir Lossky, A l' image et a la rencontre de Dieu, Paris, 1967, p. 23
} 
to point out that the elaboration of this theory was not the effect of a spontaneous discovery ${ }^{69}$, but only one of many "made" methods in order to break man from God both in his origin, in his historical existence, but also by asserting another purpose of human life. Beyond the fact that this theory is rather a belief ${ }^{70}$, a doctrine, a philosophy and not a scientifically proven fact $^{71}$, the effect produced was the inoculation of the idea that being modern means being an evolutionist, as if it had been more shameful for man to be the creature of God than to have the wild (imaginary, in fact) man of Cro-Magnon or man of Neanderthal as his ancestor.

3. Mankind is often troubled by various pseudo-apocalyptic messages that arise from different corners of the world and herald an imminent end of our planet, causing an irrational fear or anguish in people's subliminal. Moreover, today's flavour for these pseudoapocalyptic "flashes" seems to be given by their scientific character. They are even issued by worldwide recognized entities in the field (e.g. NASA, WHO etc). These warnings, although scientifically based, receive a false apocalyptic aura, especially from the media. This state of affairs demanded that we elaborate a mature answer from the point of view of eschatological theology. The answer that can deconstruct such pseudo-apocalyptic messages can be offered by rational, logical, historical and theological argumentation. An essential argument lies in the development of the eschatological theme of the $\mathrm{End}^{72}$, a theme received in the media space and in daily life in a distorted way. The End should not be understood in the absolute and restrictive sense of this word in the first place, but as a "boundless boundary"73 of the world, and so as a new beginning of it in another dimension. The End, in the orthodox tradition, has a positive connotation, because it is not seen as an entry into nothingness, but as a transfiguration towards a better state, as the achievement of the world's full ontological ideal. Regardless of the catastrophic events that occur around the world, the end will not come from within the world, because it itself is not capable of such radical events, because it was neither capable of self-creation nor of establishing its internal rationality that forms the basis of its existence and functionality, nor to save itself from the Adamic catastrophe. Along with the beginning and salvation, the end belongs to God.

The manifestation of a human attraction for the pseudo-apocalyptic must also be admitted as being real. A possible answer could be given by the idea that in the collective subliminal, a truly new, revolutionary event is expected, an event that will no longer be produced by humanity itself, but by Someone beyond this world. That is why today we encounter both those New Age movements, as well as the confusing visions of the end of the world. The correct attitude towards the eschatological message of Christ is expressed in the writings of the Holy Apostles, but also of the Fathers of the Church, as ones who have noticed the attraction of people for the sensational, neglecting the important and redeeming aspects of a life in Christ. Here is an excellent example and a healthy vision expressed in the teachings of a contemporary parent from Mount Athos, recently passed to the Lord, Saint Paisie the Agiorite, who, when asked to say something about the Antichrist, responds: "Lets

\footnotetext{
${ }^{69}$ It is not by chance that the theory of evolution appears only five years after the French Revolution, being initiated by Charles Darwin's grandfather, Erasmus (Malcolm Bowden, True Science agrees with the Bible, pp. 23-36 ).

${ }^{70}$ J. H. Randall, The making of Modern Mind, p. 475

71 Ierom. Serafim Rose, Cartea Facerii, Crearea lumii și omul începuturilor.Perspectiva creștin-ortodoxă [Genesis, Creation and Early Man], traducere de Constantin Făgețan, Editura Sofia, București, 2001, pp. 182$183,206 \ldots$

${ }^{72}$ Pr. dr. Petre Mădălin Ștefan, Eshatologia ortodoxă, pp. 351-358

73 Cuv. Nichita Stithatul, "Cele 300 de capete despre făptuire", in Filocalia, vol. VI, traducere de pr. prof. Dumitru Stăniloae, Editura Humanitas, București, 2004, p. 308
} 
better say something about Christ ... As much as we can, we should be near Christ. If we are with Christ, shall we fear the Antichrist? Isn't it there an anti-Christian spirit now? It is the evil that makes the anti-Christian spirit. And if an anti-Christ monster is born and will do some wickedness, it will be laughed at the end"74. The same thought is also expressed by the learned father Serafim Rose: "We should not count the years or calculate who is the 'King of the South', the 'King of the North', etc., but go deeper with things. The same first Apostles, in their epistles, write about the necessity of thinking that Christ is near, in order to get prepared, and be above all, spiritually prepared. If we are not in this waiting state for Christ, ready for Him to come to us, in the spiritual sense, either to meet our own souls by means of His divine grace, or in the hour of our death, then the problem of His physical coming to this earth at the end of the world will not disturb us so much so as to to enter a new sect that goes to the top of the mountain and waits for that day to come. We do not know the day and the hour, the fundamental priority is the spiritual preparation"75. In other words, the obsession with the latter events leads to the neglect of the present, from which the future hangs.

Of course, the Church has never chosen the solution of painting the reality in bright colors, no matter how harsh the reality may be, but, from the eschatological perspective, it urges Christians to "worry in the good sense"76 and to be wise. It is true that in the cult of the Church, but also in the ascetic-mystical writings, they predominantly refer to an impending end, but to an end that concerns each one of us separately, therefore to each one's personal death, with the purpose of awakening the soul for repentance and for attachment to Christ.

A deeper look at the history of mankind indicates that it is not determined by chance, but beyond its shadows, history is discreetly conducted by the unseen hand of God. $\mathrm{He}$ is the one who keeps the history of mankind in a certain unity. This dynamic unity of human history would be difficult to recognize if we only considered its movement on the immanent scale and were not guided towards decipher its meanings inscribed in meta-history. The Holy Scripture, for example, is the true history, because it records history as a symbiosis of both planes, the vision being vertical and not horizontal ${ }^{77}$. In The Holy Scripture history is complete, not at the informational level, but substantially, so that, beyond its other aspects, "in its entirety, Scripture is not image and allegory, but history" of man and God ${ }^{78}$. Besides, the history recorded in The Scripture begins with the creation of the world and of man, and continues with the preparation of humanity through the chosen people for the coming into the world of the Son of God. The history's center part is given by the descent of the Son of God and the founding of the Church, and the telos of history is none other than the return of Christ and the renewal of creation. So, it is as clear as possible that the reins of history are still in the hands of $\mathrm{Christ}^{79}$.

\footnotetext{
${ }^{74}$ Cuv. Paisie Aghioritul, Trezire duhovnicească, Editura Evanghelismos, București, 2003, p. 189

${ }^{75}$ Serafim Rose, God's Revelation to the Human Heart, St. Herman of Alaska Botherhood, 1987, p. 58

${ }^{76}$ Cuv. Paisie Aghioritul, Trezire duhovnicească, p. 207

${ }^{77}$ Olivier Clement, „Quelques notes sur la spiritualité du starets Silouane”, in Contacts, No. 184 (1998), p. 289

${ }^{78}$ George Florovski, Biserica, Scriptura, Tradiția [Bible, Church, Tradition], Editura Platytera, București, 2005, p. 161

${ }^{79}$ Early Christians believed that Christ continued to rule the world from heaven, so the world's destinies were no longer in the hands of tyrannical monarchs, but in the hands of the Lord. Therefore, martyrs often confessed that obedience was due first to the King of Heaven and earth and then to the earthly king. In an epistle of the Church of Smyrna, the accounts on the martyrdom of Saint Polycarp indicate this belief in Christ's reign throughout history: "Saint Polycarp died a martyr on the second day of the month of Xanth (February), seven days before the calends of March, on Holy Saturday, around eight o'clock. He was captured by Herod, when Philip Tralianus was bishop, Statius Quadratus proconsul, and Jesus Christ emperor of the ages, to whom be due glory,
} 


\section{CONCLUSION}

It is obvious that postmodernity and modernity don't differ in their substance, but in their expression. The postmodern age continues the big changes in the noological structure of social life, changes started in the modern age, but the methodology of the new „emancipation” was reviewed and adapted to a different society. The experience that started with the French Revolution and ended with the communism did not succeed in excluding the Christian faith from the structure of the human life, but did exactly the opposite. Consequently, secularizing actions had to be dressed in irenic clothing, knowing that man is conquered more easily by pleasure than by pain. Although postmodernity does not define itself using the violent, revolutionary atheism that characterized the modern era, when it relates to God, it presents an even greater threat for the man. In other words, the atheism of the past era, declared directly and hatefully, soon led to the opposite effect, to the intuition of the abnormality or emptiness produced by challenging the Divine Truth. The postmodern currents have succeeded more effectively in blurring the faith in God through irenic and relativistic methods, whose negative effect no longer produce an alarm signal for man. This result was achieved by presenting a "softer" alternative, more accessible than faith and living in God. It is true that, in our time, there is a persistence to feed the man with such surrogates and to artificially arouse a multitude of "needs", which, in fact, distract him from the serious things of life.

\section{BIBLIOGRAPHY:}

[1]Biblia sau Sfânta Scriptură [Holy Scripture], tipărită cu binecuvântarea, P. F. Teoctist, Patriarhul B.O.R., Bucureşti 1991

[2] Afanasiev, Nikolai N., Canoane şi conștiință canonică, traducere de Constantin Făgețean, Editura Egumenița, Galați, 2005

[3] Andreff, W., Les multinationales globales, La Découvert, 1996

[4] Atanasie cel Mare, Sfântul, "Tratat despre Întruparea Cuvântului și despre arătarea Lui în trup”, PSB 15, Editura Institutului Biblic și de Misiune al Bisericii Ortodoxe Române, București, 1987

[5]Berdiaev, Nikolai, Essai de métaphysique eschatologique, Aubier, Paris, 1946

[6]Besancon, Alain, The Forbidden Image: an Intellectual History of Iconoclasm, translated by Jane Marie Todd, Chicago, 2009

[7]Bowden, Malcom, True Science agrees with the Bible, Sovreign Publications, Bromley, 1988

[8]Bréhier, L., La querelle des images (VIII-Ixe siècles), II éd., Paris, 1904

[9] Calist Patriarhul, "Capete despre rugăciune" [About Prayer], in Filocalia, vol. VIII, traducere de pr. prof. dr. Dumitru Stăniloae, Editura Institului Biblic și de Misiune al Bisericii Ortodoxe Române, București, 1979

[10] Clement, Olivier, Sillons de lumière, Fatest/ Cerf, Troyes, 2002

[11] Clement, Olivier, "Quelques notes sur la spiritualité du starets Silouane", in Contacts, No. 184 (1998)

[12] Chelcea Septimiu, Cum să redactăm o lucrare de licență, o teză de doctorat, un articol științific în domeniul științelor socioumane, București, 2003

[13] "Martiriul Sfântului Policarp, episcopul Smirnei, in Actele martirice, PSB, vol. 11, traducere de pr. prof. Ioan Rămureanu, Editura Institutului Biblic și de Misiune al Bisericii Ortodoxe Române, București, 1982

[14] Evdokimov, Paul, Femeia și mântuirea lumii [Woman and the Salvation of the World], traducere de Gabriela Moldoveanu, Editura Christiana, București, 1995

honor, exaltation, everlasting kingdom from generation to generation. Amen" ("Martiriul Sfântului Policarp, episcopul Smirnei", in Actele martirice, PSB, vol. 11, traducere de pr. prof. Ioan Rămureanu, Editura Institutului Biblic și de Misiune al Bisericii Ortodoxe Române, București, 1982, p. 34) 
[15] Evdokimov, Paul, Iubirea nebună a lui Dumnezeu [L'amour fou de Dieu], [The foolish Love of God], traducere de Teodor Bakonsky, Editura Anastasia, București, 1999

[16] Evdokimov, Paul, Cunoașterea lui Dumnezeu în Tradiția răsăriteană [La conaissance de Dieu selon la tradition orientale], traducere de Pr. Vasile Răducă, Editura Humanitas, București, 2013

[17] Florovski, George, Biserica, Scriptura, Tradiția [Bible, Church, Tradition], Editura Platytera, București, 2005

[18] Florenski, Pavel, The Pillar and Ground of the Truth, Oxford University Press, 2004

[19] Grabar, A., Iconoclasmul bizantin, Editura Meridiane, Bucuresti, 1991

[20] Guénon, René, La crise du monde moderne Les Editions Gallimard, Paris, 1946

[21] Hawking, Stephen, A brief History of Tim, 1988

[22] Hawking, Stephen, Black Holes and Baby Universes and others essays, 1993

[23] Ică, Ioan I. jr., "Globalizarea - mutații și provocări" [The Globalization - Mutation and Challenge], in Ioan I. Ică jr., Germano Marani, Gândirea socială a Bisericii[The social Thinking of the Church], Editura Deisis, Sibiu, 2002

[24] Ierotheos, Mitropolitul Nafpaktosului, Dogmatica empirică după învățăturile prin viu grai ale părintelui Ioannis Romanidis [The Empirical Dogmatic after the Oral Teachings of Father Ioannis Romanides], Vol. I, traducere de Tatiana Petrache, Editura Doxologia, 2014

[25] Ioja, Cristinel, "Sensul istoric-eshatologic al culturii și contrafacerile acestuia în cadrul culturii secularizate [The Historical-Eschatological Meaning of Culture and its Counterfeits in the Framework of the Secularized Culture]", in Studia Universitatis Babeș-Bolyai. Theologia Orthodoxa, vol. 57, 2 (2012)

[26] Krivoșein, Arhiepiscop Vasile, Biserica sobornicească, traducere de Nicolae Crețu, Editura Sofia, București, 2012

[27] Little, Henry George; Scott, Robert, A Greek-English Lexikon, Clarendon Press, Oxford, 1996

[28] Lossky, Vladimir, A l' image et a la rencontre de Dieu, Paris, 1967

[29] Lossky, Vladimir, Teologia mistică a Bisericii de Răsărit [The Mystical Theology of the Eastern Church], Editura Anastasia, București, 1995

[30] Marrou, Henri-Irenéé, Theologie de l'histoire, Cerf, Paris, 2006

[31] Maxim Mărturisitorul(Sfântul), Mistagogia[Mistagogy], traducere de pr. Prof. Dumitru Stăniloae, Editura Institutului Biblic și de Misiune al Bisericii Ortodoxe Române, București, 2000

[32] Maxim Mărturisitorul (Sfântul), Ambigua, traducere de pr. prof. Dumitru Stăniloae, Editura Institutului Biblic şi de Misiune al Bisericii Ortodoxe Române, București, 2006

[33] Nedelcu, Marius, "Conferință despre simbolistica modernă", in Ziarul Lumina, 16 iunie 2016

[34] Ozoline, Nicolas, "The Theology of The Icon", in The Greek Orthodox Theological Review, 1/4 (1993)

[35] Paisie Aghioritul (Cuviosul), Trezire duhovnicească [Spiritual Awekening], Editura Evanghelismos, București, 2003

[36] Patapievici, H.-R.,Omul recent [The recent Man], Editura Humanitas, București, 2011

[37] Petre, Rev. Assist. PhD Mădălin Ștefan, "Un synthése de la theologie eschatologique orthodoxe", in Journal Orthodox Theology in Dialogue, No. 4 (2018)

[38] Petre, Pr. dr. Mădălin Ștefan, Eshatologia ortodoxă. Raportul dintre eshatologia inaugurată la Cincizecime, eshatologia incoativă și eshatologia finală sau realizată a Cetății ce va să fie [Orthodox eschatology. The relationship between the eschatology inaugurated at Pentecost, the inchoate eschatology and the final or accomplished eschatology of the City that will be], Editura Mitropolia Olteniei, Craiova, 2019

[39] Pleșu, Andrei, Despre frumusețea uitată a lumii [About forgotten Beauty of the World], Editura Humanitas, București, 2011

[40] Popovici, Sf. Iustin, Abisurile gândirii și simțirii umane, traducere de pr. Dr. Gabriel Mândrilă și Laura Mândrilă, Editura Sofia, București, 2013

[41] Randall, J. H., The Making of Modern Mind, Mufflin Company, Houghton, 1940

[42] Romanidis, Ioannis, Teologia patristică [Patristic Theology], traducere de pr. Dr. Gabriel Mândrilă, Editura Metafraze, București, 2011 
[43] Rose, Serafim, God's Revelation to the Human Heart, St. Herman of Alaska Botherhood, 1987

[44] Rose, Eugene (Fr. Serafim), Nihilism. The Root of the Revolution of the Modern Age, Saint Herman of Alaska Brotherhood, Platina-California, 2001

[45] Rose, Ierom. Serafim, Cartea Facerii, Crearea lumii și omul inceputurilor.Perspectiva creștinortodoxă [Genesis, Creation and Early Man], traducere de Constantin Făgețan, Editura Sofia, București, 2001

[46] Saharov, Arhim. Sofronie, Cuvântări duhovniceşti, traducere de Ierom. Rafail Noica, Editura Reîntregirea, Alba Iulia, 2004

[47] Schmemann, Alexandre, Euharistia-Taina Împărăției [The Eucharist: Sacrament of the Kingdom], traducere de Pr. Boris Răduleanu, Editura Anastasia, București, 1993

[48] Schooyans, Michel, La dérive totalitaire du libéralisme, ed. II, Mame, Paris, 1995

[49] Siluan Athonitul (Sfântul), Între iadul deznădejdii și iadul smereniei, traducere de diac. Ioan I. Ică jr, Editura Deisis, Sibiu, 2001

[50] Stăniloae, Pr. Prof. Dumitru, Teologia dogmatică ortodoxă [Orthodox Dogmatic Theology], vol. II, Editura Institului Biblic și de Misiune al Bisericii Ortodoxe Române, București, 2003

[51] Stithatul, Cuv. Nichita, "Cele 300 de capete despre făptuire", in Filocalia, vol. VI, traducere de pr. prof. Dumitru Stăniloae, Editura Humanitas, București, 2004

[52] Vasiliev, A. A., Istoria imperiului bizantin[History of the Byzantine Empire], traducere de IonuțAlexandru Tudorie, Vasile-Adrian Carabă, Sebastian-Laurențiu Nazâru, Editura Polirom, Iași, 2010

[53] *** A Theological Dictionary, Philadelphia, 1838

[54]*** "Păstorul lui Herma", Porunca I, in Scrierile Părinților Apostolici, PSB, vol. 1, Editura Institului Biblic și de Misiune al Bisericii Ortodoxe Române, București, 1979

[55] *** 322 de vorbe memorabile ale lui Petre Țuțea, Editura Humanitas, București, 1997

[56] *** The Cambridge Dictionary of Philosophy, Cambridge University Press, 1999 